\title{
To KeEp Me Safe From HARM? \\ TRANSGENDER PRISONERS \\ AND THE EXPERIENCE OF IMPRISONMENT
}

\author{
RICHARD EDNEY*
}

[The experience of imprisonment for a transgender person is often a terrifying one. He or she is extremely vulnerable in such an environment from sexual violence from other prisoners. In addition, he or she may be exposed to inadequate or inappropriate medical care. Consequently transgender prisoners are often denied the protection offered by rule of law. A significant reason for this treatment is the erasure of the transgender experience in informing the nature of the prison regime. In particular, the failure to give sufficient weight to gender self identification by transgender prisoners exposes them to risks which other prisoners do not have to endure. It is suggested that the only way to reduce such harm is through the cultivation of a prison regime based upon the lives of transgender prisoners.]

\footnotetext{
* Senior Lecturer, School of Law, Deakin University. Address for correspondence: richard.edney@deakin.edu.au. My thanks to Karen Gurney and Sandra Pyke for research assistance. Of course, all errors and omissions remain that of the author.
} 


\section{INTRODUCTION}

As a class prisoners are generally considered to have their institutional lives marked by a high degree of vulnerability. ${ }^{1}$ This is primarily due to those endogenous features of the prison environment which vests correctional administrators with significant power over central aspects of prisoners' daily lives. The exercise of such power reduces significantly the autonomy of prisoners. ${ }^{2}$ The 'totalising' nature of the prison as an institution results in the creation of a particular subculture with certain norms and behaviours. ${ }^{3}$ Such features of the prison environment add to the dimensions of vulnerability encountered by prison inmates. However, not all prisoners are equally positioned in terms of their vulnerability to the privations that accompany prison life. In particular, the literature in existence on transgender prisoners, impoverished as it is, suggests a disproportionate level of vulnerability for transsexual prisoners as a discrete population. ${ }^{4}$ Arguably the vulnerability and harm experienced by transgender prisoners is a continuum, into the prison context, of high levels of social exclusion and discrimination that exists in the general community towards transgender individuals. ${ }^{5}$ In short, it is part of a process where significant aspects of transgender lives are 'erased' by dominant institutional practices. $^{6}$

\footnotetext{
${ }^{1}$ Richard Edney, 'Judicial Deference to the Expertise of Correctional Administrators: The Implications for Prisoners' Rights' (2001) 7 Australian Journal of Human Rights 91, 103-106.

${ }^{2}$ Gresham Sykes, The Society of Captives (1958) 63-79.

${ }^{3}$ See generally Donald Clemmer, The Prison Community (1941)

${ }^{4}$ An excellent overview is provided by Jake Blight, Transgender Inmates: Trends and Issues in Crime and Criminal Justice (2000) 5-6.

${ }^{5}$ See for instance the apposite comments of Diane Richard, who notes the following: 'Being transgendered puts men and women at extreme risk of being ridiculed and humiliated, being at constant jeopardy over getting and keeping a job, being evicted without cause from restaurants and stores, being denied housing and being refused medical treatment, even to save a life'. (3-4)

Diane Richard, 'Trans Behind Bars: Officials, Activists Struggle with Options' (2000) 34 Contemporary Sexuality 1.

${ }^{6}$ See generally Viviane K Namaste, Invisible Lives: the Erasure of Transsexual and Transgendered People (2000).
} 
The concern here is with transgender prisoners ${ }^{7}$ and how they are constructed as "objects" by the particular relationship between life and law in the prison environment. In particular, it is proposed to utilise the analytical category of 'erasure' to account for the treatment of transgender inmates that at the same time objectifies, but also renders invisible, the experiences and concerns of transgender prisoners. As such, transgender prisoners are not only exposed to harm because of inadequate and inconsistent medical treatment, but encounter a significantly higher risk of sexual assault while in prison. In particular, a stunning feature of this invisibility in practice is the general lack of formal policies that would recognise the inherent difficulties for transsexual prisoners of confinement and the need to change salient features of an institution such as the prison. Indeed, an international survey of correctional services policies found that only approximately $20 \%$ of corrections departments had in place formal policies for transgender prisoners. ${ }^{8}$ The 'lack of an established policy ${ }^{\prime}$ indicates a lack of care and concern for the experience of transgender prisoners.

In that sense the concern is one of retrieval in an attempt to interrogate the existing understandings of the relationship between the transgender prisoners, law and the prison order. Such an approach has as its fundamental premise the notion that any correctional policy and legal instrument designed to assist transgender prisoners must take account of this difference and the unique experiences of transgender prisoners in the correctional environment.

\section{The Transsexual Experience of the Prison}

As part of any project to take seriously the concerns of transgender prisoners it is critical to take into account the precise details of the treatment of transgender persons by the criminal justice system. Without such a basic understanding of the effects of the prison system upon transgender persons it is not possible to imagine a

\footnotetext{
${ }^{7}$ I note that there is significant debate within the transgender community concerning the use of appropriate language to describe the experience of transgender persons. I rely on the definition proposed by Kartina Rose:

A transsexual is an individual whose internal sense of being male or female is at variance with his or her physical appearance and desires to correct the variance via hormone treatment and/or surgery. "Transgender", as it is widely used today, is an umbrella term which includes not only transsexuals but also other categories of gender-variant people, and though it had originally been used to refer to transsexuals who, though hormonally altered

living as members of the opposite gender, ultimately opted not to have sex reassignment surgery.

See Katrina Rose, 'When is an Attempted Rape Not an Attempted Rape? When the Victim is a Transsexual' (2001) 9 Journal of Gender, Social Policy and the Law 505, 506 n 2.

${ }^{8}$ Maxine Petersen, Judith Stephens, Robert Dickey and Wendy Lewis, 'Transsexuals within the Prison System: An International Survey of Correctional Services Policies' (1996) 14 Behavioral Sciences and the Law 219, 221-222. Countries involved in the survey included Australia, Canada, United States and members of the European Community.

${ }^{9}$ Ibid 226.
} 
prison order that would incorporate the epistemological insights that have been generated by transgender communities and individuals. ${ }^{10}$ The United States Supreme Court decision of Farmer $v$ Brennan ${ }^{11}$ provides a salient example of what may be described as a typical, or at the least, not unusual experience for a transgender inmate and the significant harm attributable solely to the fact of her transsexualism. In this decision we have an attempt by the plaintiff, Dee Farmer, to remedy the wrongs suffered by her during her incarceration. At the relevant time, Farmer was serving a federal prison sentence for matters of dishonesty. The Federal Bureau of Prisons had diagnosed Farmer as a transsexual and described her as a person having a

...rare psychiatric disorder in which a person feels persistently uncomfortable about his or her anatomical sex. ${ }^{12}$

The Court noted that a person who endures this condition 'typically seeks medical treatment, including hormonal therapy and surgery, to bring about a permanent sex change'. ${ }^{13}$ It appears from the decision in Farmer that the practice of the Federal Bureau of Prisons was to place 'preoperative transsexual prisoners with prisoners of like biological sex'. ${ }^{14}$ Within such a framework the Federal Bureau of Prisons made an assumption that sex, as indicated in the presence of male or female genitals, was equivalent to gender. ${ }^{15}$ Such an assumption is wrong in that it not only defies recognised medical and psychiatric definitions of gender dysphoria, but ignores the lived, subjective reality of transgender persons. In Farmer, the evidence disclosed that the plaintiff 'wore women's clothing,..., underwent estrogen therapy, received silicone breast implants, and submitted to "black market" testicle removal surgery'. ${ }^{16}$ In addition, the parties were joined on the issues that the plaintiff "projects feminine characteristics'. ${ }^{17}$

Despite the clear evidence that the plaintiff was living, as best as she could, as a woman while in custody, the Federal Bureau of Prisons continued with her incarceration in a male facility. Thus sex, rather than self conceptions of gender, ruled her classification. During her time in custody, Farmer was transferred between various Federal prisons and was segregated because of safety concerns. Ultimately she was transferred to a United States Penitentiary and placed in the general male

\footnotetext{
${ }^{10}$ In this manner, the activism of the transgender community is broadly similar to the methods adopted in feminist struggles and, in particular, the concept of 'consciousness raising'. The benefit of this method is that it takes seriously the personal experiences of those exposed to an oppressive social order. Such experiences of exclusion and discrimination and their narration are viewed as a necessary part of that social change. See also Martha Minnow, Making All the Difference: Inclusion, Exclusion and American Law (1990) 196-200.

${ }^{11}$ (1994) 511 US 825.

12 Ibid 827 (Souter J).

13 Ibid (Souter J).

14 Ibid, 828 (Souter J).

15 Anita Barnes, 'The Sexual Continuum: Transsexual Prisoners' (1998) 24 New England Journal of Criminal and Civil Confinement 599, 600-602.

${ }^{16}$ (1994) 511 US 825

${ }^{17}$ Ibid.
} 
prisoner population. Within two weeks Farmer was raped by another inmate in her own cell. ${ }^{18}$

The factual matrix in Farmer typifies one of the most likely sources of danger for the transgender inmate: placement in an inappropriate custodial situation. Typically such inappropriate placement arises as often the key classificatory tool of correctional authorities is to place an inmate on the basis of his or her genitals or biological sex. The self concept of the transgender prison appears to have little, if no weight, in the decision of classification. As such, the assessment appears to occur on a physical examination of the prisoner. Such an assessment conflates sex and gender when there is not necessarily such a correlation. Indeed, the nature of gender dysphoria $^{19}$ is precisely what correctional authorities generally ignore in the important task of prisoner classification. The consequences for the transgender prisoner are enormous in terms of threats to bodily integrity and psychological functioning. Thus to place, for instance, an individual who is a biological male, but who identifies and lives as a female in a male correctional environment is to place her at significant risk of harm. The consequences of such an inappropriate placement were evident in Farmer $v$ Brennan. In addition, it ignored completely how she has defined herself and placed her in a position in such an environment that what in the end occurred was hardly surprising.

\section{Sexual Violence and Transgender Prisoners}

Sexual violence against transgender prisoners must be at the forefront of any analysis of the relationship between life and law in the context of the prison. To the extent that a prison order cannot protect transgender prisoners from predatory behaviour of other inmates, there necessarily arises a problem of legitimacy in the punishment of transgender prisoners. Part of the susceptibility of transgender prisoners to sexual assault in the prison setting is the excessively masculine nature of the prison environment. ${ }^{20}$ In such an environment, acts and threats of rape become forms of intimidation and domination as well as strategies by certain prisoners to

\footnotetext{
${ }^{18}$ It was as a result of this transfer and placement in the Federal Penitentiary that the plaintiff's cause of action arose. Farmer pleaded that the correctional authorities' action violated her constitutional rights under the $8^{\text {th }}$ Amendment to the United States Constitution that prohibits 'cruel and unusual punihsment'. Previous authorities of the United States Supreme Court have held that, in determining whether or not correctional authorities had breached a prisoners constitutional rights, there had to be a consideration as to whether or not correctional authorities acted with 'deliberate indifference' to the rights of the petitioner. This is a difficult standard for prisoners to achieve as it requires establishing a subjective knowledge on the part of the defendants that they actually knew of the risks to a prisoner and deliberately ignored or were indifferent to such a risk. It was on this basis, and the failure to prove that the relevant corrections officials had possessed that requisite specific knowledge that Farmer was ultimately unsuccessful. It was accepted by the Court that she had been raped.

${ }^{19}$ For an overview of those theories see generally Louis Lothstein, 'Psycho-dynamics and Socio dynamics of Gender Dysphoric States' (1979) 33 American Journal of Psychotherapy 214.

${ }^{20}$ See generally Don Sabo, Terry Kupers \& Willie London (eds), Prison Masculinities (2001).
} 
control other prisoners. As has been found numerous studies, rape in male prison is a distinct aspect of the prison experience, particularly for young offenders. ${ }^{21}$

Empirical data on prison sexual violence suggest that it is not a random activity, but arises from the choosing of particular victims who for one reason or another are believed to be more vulnerable. ${ }^{22}$ The data also strongly suggests that not only youth, but also feminine characteristics are important factors in determining whether or not a person becomes a victim of sexual violence. Support for a particular regime of victimization for transgender prisoners is also evident in the study undertaken by Human Rights Watch concerning the phenomena of male rape in United States prisons. ${ }^{23}$ That report found the following:

...prisoners fitting any part of the of the following description are more likely to be targeted: young, small in size, physically weak, white, gay, first offender, possessing "feminine" characteristics such as long hair or a high voice; being unassertive, unaggressive, shy, intellectual, not street-smart, or "passive", ${ }^{24}$

The implications for such prisoners were significant in that

prisoners with any one of these characteristics typically face an increased risk of sexual abuse, while prisoners with several overlapping characteristics are much more likely than other prisoners to be targeted for abuse. ${ }^{25}$

The failure of prison administrators to accord transgender prisoners such a basic level of protection when it is likely, given the state of empirical knowledge, that such harm will occur to them is of great concern. ${ }^{26}$ It is clearly a breach of the duty of care owed by correctional authorities to provide protection of such inmates from others who may commit such acts of harm. ${ }^{27}$ In addition, it amounts to a failure to guarantee the human rights of such prisoners and to provide basic protections concerning privacy, security and bodily integrity. ${ }^{28}$

\footnotetext{
${ }^{21}$ See David Heilpern, Fear or Favour: Sexual Assault of Young Prisoners (1998). Also see Neer Korn, Life Behind Bars: Conversations with Australian Male Inmates (2004); Lee Bowker, Prison Victimization (1980); David Cooley, 'Criminal Victimization in Male Federal Prisons' (1993) 35 Canadian Journal of Criminology 479.

${ }^{22}$ Richard Wortley, Situational Prison Control: Crime Prevention in Correctional Institutions (2002) 103-105.

${ }^{23}$ Human Rights Watch, No Escape: Male Rape in United States Prisons (2001). Available on-line at <http://www.hrw.org/reports/2001/prison/report4.html>

${ }^{24}$ Ibid.

${ }^{25}$ Ibid.

${ }^{26}$ It also appears to be an example of the manner in which institutional practices ignore the experience of transgendered persons. See Namaste, above n 6, 260-271.

${ }^{27}$ Lv Commonwealth (1976) 10 ALR 269.

${ }^{28}$ And, as such, an illustration of the marked dissonance between the legal system and the lives of transgendered individuals. For an excellent account that exposes the extent of making invisible such experiences see Katrina Rose, 'When is an Attempted Rape Not an Attempted Rape? When the Victim is a Transsexual' (2001) 9 Journal of Gender, Social Policy and the Law 505.
} 
The consequences for individuals of this malign neglect can be catastrophic. In the case of Catherine Moore, who was being held on remand in a New South Wales Prison in late 1997, this led to her suicide. ${ }^{29}$ In her case, Catherine had been placed within the protection unit because of her overt feminine characteristics. Despite this placement, Catherine was raped by a male prisoner. Soon after Catherine committed suicide through the ingestion of a number of illicit drugs. The Coroner found that the suicide was as a result of that sexual assault and the conjunction of the provision of drugs by an unidentified inmate. ${ }^{30}$ In terms of recommendations the Coroner suggested that the prison policy should be designed so that it results in an outcome that would 'house transgender prisoners in institutions appropriate to their gender identification'. 31

\section{Protection FROM VULNERABILITY OR DISPROPORTIONATE PUNISHMENT?}

Another problematic feature of the placement of transgender prisoners in prisons incongruent with their gender identity is that often they are placed in 'protection'. The problem with this, apart from the fact that it does not always guarantee safety, is that transgender prisoners endure more onerous conditions than other inmates. In particular, placement in such isolation may produce negative psychological consequences. As was described by Robin, the experience of such isolation simply compounded her difficulties:

The first day was very hard. I was at Bathurst only 12 months because of not being able to understand me. They kept me in what they called the Back Yard where no-one else could see me, and this kind of treatment I couldn't stand because I was by myself. It was a yard 20 by 10 ; I was there all day and back to my cell at night time. I had no company and it actually drove me mad, so I became a little suicidal. I told them if they didn't shift me I would probably end up a lunatic or something. And eventually I - I ended up attacking one of their prison officers, and was given 28 days for assault. ${ }^{32}$

The significance of this quote is manifold. First, it represents the dehumanisation of the transgender prisoner by the correctional environment. Robin is kept away from other prisoners and hidden as if she was the source of the problem. Second, the practice, which arose primarily because Robin had not been placed in a female prison, of isolating her provoked negative psychological consequences including

\footnotetext{
${ }^{29}$ Catherine Renshaw, 'The Death of Catherine Moore: The Predicament of Transgender Prisoners' (1999) 3 Australian Lawyers for Human Rights 1.

${ }^{30}$ Ibid 2.

${ }^{31}$ Ibid 2.

${ }^{32}$ Chris Sanderson, 'Experiences of a Transsexual Prisoner' (1984) 9 Legal Service Bulletin 183, 184.
} 
suicidal ideation. Finally that the practice itself of isolation was in the end counter productive to the security and good order of the prison in that Robin intentionally assaulted a prison officer so that she would be transferred. In the United States context, Barnes notes the manner in which such administrative segregation undermines the legal rights of the transgender prisoner:

Placing transsexual prisoners in protective custody, given their status, compounds the unconstitutionality of such a practice. Although a legitimate safety concern exists, segregation for protective reasons limits a prisoners' privileges and constitutional rights. Ultimately such confinement becomes punitive and results in a disproportionate sentence. ${ }^{33}$

What this effectively means is that the transgender prisoner, through no fault of their own, is subject to less than equal treatment within the prison system and exposure to a far more punitive daily regime.

\section{The Question of Medical Treatment in Prison}

A major concern for the transgender prisoner is that he or she may not receive appropriate medical treatment for his or her condition while incarcerated. Decisions as to medical treatment appear to narrow significantly while transgender prisoners are in custody. Typically, this will depend on the prison and jurisdiction in which the prisoner is classified. ${ }^{34}$ Some jurisdictions appear to permit the continuation of therapy for inmates who prior to custody are involved in a course of hormonal therapy while others simply stop the supply of such medication upon incarceration. The question of sex reassignment surgery is generally even more contentious with few jurisdictions providing such support. ${ }^{35}$ However maintaining hormonal levels for a transsexual prisoner who has been using such hormones prior to incarceration does not necessarily guarantee an appropriate level of medical treatment. As Joslin notes, in the context of discussing the United States Bureau of Prisons medical treatment policy for transsexual prisoners:

Even if the prison does provide hormones, however, there is no guarantee that they will be provided at the appropriate levels and with necessary physical and psychological support services. In addition, it is often difficult for transsexual prisoners to document a prior prescription for hormones, either because of the practical difficulties and limitations imposed by incarceration, or because many transsexual prisoners are indigent and do not have private physicians

\footnotetext{
${ }^{33}$ Barnes, above, n 15, 644.

${ }^{34}$ Petersen, Stephens, Dickey and Lewis, above $\mathrm{n} 8$.

${ }^{35}$ Ibid.
} 
willing to advocate for them. Moreover, even when transsexual prisoners are able to provide sufficient documentation, prison officials may disregard or flout the policy. ${ }^{36}$

Such a position appears to rely in particularly on medical evidence and testimony from a treating medical practitioner of the patient who wishes to undergo sexual reassignment surgery to 'live like' the member of the sex they wish to change to. The ability to achieve such 'real life' experience is difficult for the transgender prisoner. This is particularly the case in relation to long term prisoners given the preferred approach of most correctional authorities is to 'freeze frame' transgender inmates. ${ }^{37}$ Such a policy ignores the significant difficulties caused to a transgender prisoner having to wait until he or she is released to secure proper medical treatment. In some ways, there appears a tacit assumption that the choice to undertake such a regime of choice is simply a cosmetic decision, rather than treatment fundamental to psychological well being and the ability to flourish. Such a trivialisation of the significance of obtaining appropriate medical treatment was evident in the Equal Opportunities Division of the New South Wales Administrative Decisions Tribunal decision in Lawarik $v$ Chief Executive Officer, Corrections Health Ser$v_{\text {vice }}^{38}$ where the condition of the transgender prisoner applicant was described as being of the type 'where the condition is not urgent or life threatening'. ${ }^{39}$ Thus again showing the failure to take seriously the concerns of the transgender prisoner. Contrast the approach in Lawarik with a perspective provided by Gianna Israel that is underpinned with the lived experiences and subjective realities of transgender prisoners:

Most prisons do not provide hormones, and some go to great lengths to avoid providing any treatment to transsexual inmates. Most transsexual inmates are not receiving appropriate medical and psychological care. Many repeatedly seek medicial treatment, often for years, while enduring administrative harassment and difficult court battles in the pursuit of basic medical and civil rights. Prisons that do provide frequently have policies which allow for the treatment of those who were treated prior to incarceration, but fail to address the medical needs of those who develop Gender Identity Disorder during incarceration or who have no documented proof of their preincarceration transsexualism. Officials often claim that only those inmates who were diagnosed with Gender Identity Disorder and placed on hormones before incarceration are eligible for hormones in prison. They sometimes maintain that the prison does not afford the opportunity for the real life experience,..., conveniently ignoring the fact that

\footnotetext{
${ }^{36}$ Courtney Joslin, Transsexual Prisoners (2002) 1-2. Available on-line at <http://www.nclrights.org/publications/ts prison.htm>.

${ }^{37}$ Petersen, Stephens, Dickey and Lewis, above n 8, 226.

${ }^{38}$ [2003] NSWADT 16 (24 January 2003).

${ }^{39}$ Ibid [82].
} 
many MTF transsexual inmates consistently maintain their female identity year after year in an all male facility. ${ }^{40}$

Importantly the different perspective offered by Israel, informed as it is by a clear understanding of the position of transgender prisoners, emphasizes that the current practices of correctional administrators are neither immutable nor fixed but are instead the product of particular policy choices which may be changed.

\section{A Normative Transgender Prison Order?}

The study of the prison and the exposure of formal and informal practices has been a distinctive concern of sociologists and criminologists. Typically such accounts attempt to understand the nature or 'essence' of the prison order. ${ }^{41}$ In short, the prison is conceived as being a unique social space that is conducive to close study and analysis. Often in such accounts is the desire to compare the formal, self proclaimed aims and ends of correctional administrators with what occurs in 'practice' and to measure and explain the existence of any dissonance. In particular, there is a great deal of interest with explaining the operation and development of the informal social order known as the prison subculture.

A distinctive feature of these frameworks is the ignorance of the experiences of transgender prisoners and how they deal with the prison and counter those features of prison life which are dangerous and threatening. In short, how transgender prisoners cope, or do not, with the fact of imprisonment despite those features that would attempt to erase their experience. Race and gender are now part of the framework within which to understand the prison. Such analytical categories are deemed as crucial to understanding properly the experience of such inmates. Unfortunately, this degree of analysis or interest has yet to occur in relation to the experience of transgender prisoners in either scholarship or in terms of correctional practice.

As a consequence the experiences of confinement of transgender prisoners are placed outside the scope of analysis. In short, those experiences are accorded little weight. The absence of scholarship of that experience is part of the problem. Instead of that scholarship, and a reflexive understanding of how the prison order may be modulated to properly protect the interests of transgender prisoners, we have the pre-eminence of correctional administrators to determine how best to accommodate transgender prisoners. The empirical evidence suggests that the level of protection is not of such quality as to guarantee the basic human rights of transgender persons

\footnotetext{
${ }^{40}$ Gianna Israel, 'Transsexual Inmates Treatment Issues' (2002) 97 Transgender Tapestry 1, 4.

${ }^{41}$ See for instance Alison Liebling, Prisons and their Moral Performance : A Study of Values, Quality and Prison Life (2004).
} 
while in custody. Thus sexual violence remains a dominant and particular privation likely to be more encountered by a transgender prisoner.

In those circumstances, and given the failure of existing correctional practices to protect transgender prisoners from harm, there needs to be the development of normative prison practices that address the particular concerns of transgender prisoners. What that requires is for correctional authorities to presumptively place a transsexual prisoner in the prison of his or her self-identification. ${ }^{42}$ Part of the difficulty of current prison practice appears to be the significant power provided to correctional authorities to define the 'sex' of the transgender prisoner independently of his or her gender self conception. Such discretionary decision making directly affects whether such an individual is placed within a male or female prison. Often such placement is determined on a biological basis and through physical examination. This is inappropriate given the consequences of such a decision for the safety and liberty interests of that individual. In those circumstances self identification must be the key for the classification process as to whether or not a transgender prisoner is placed in a male or female prison or remand centre. The justification for such an approach is that the current policies and practices have been shown to be harmful to such a cohort of prisoners and given the poor level of protection offered by such a practice, a transfer of power to this aspect of classification may ultimately offer an opportunity to keep transgender prisoners safe from harm.

\section{CONCLUSION}

A small minority of transgender prisoners will at any time form part of imprisoned populations. In that sense, the fact of transsexualism will not prevent a transgender prisoner from being placed in a custodial environment. ${ }^{43}$ Traditional approaches of correctional administrators have failed to appreciate the distinction between sex and gender. Self identification of transgender prisoners has not been accorded the appropriate degree of importance in the classification, treatment and placement of transgender prisoners. Consequently, there has been less than adequate care for transgender persons who enter the criminal justice system. In particular, a reliance on the biological sex of such individuals has ignored the actual reality of transgender lives and made the experiences constituting such a life story invisible and

\footnotetext{
${ }^{42}$ Barnes, above n 15, 644-645.

${ }^{43}$ Arguably the 'threshold' requirement as to when a transsexual prisoner should receive a term of imprisonment should be higher than for a non-transsexual prisoner given the high probability of risk of harm they may suffer if incarcerated. Although there does not appear to be any authorities on this point, it is consistent with other authorities which have held that if an offender possesses certain characteristics that may make the experience of imprisonment more difficult then it should be a factor in determining whether or imprisonment is appropriate and, if appropriate, the determination of the non-parole period. For a discussion of those authorities see Richard Edney, 'Hard Time, Less Time: Prison Conditions and the Sentencing Process' (2002) 26 Criminal Law Journal 139, 143-144. Similar considerations should also apply to the question of bail.
} 
otiose to the functioning of the prison system. This is in itself not surprising given the general level of discrimination that marks the existence of transgender persons outside the correctional context.

The consequences for transgender persons of a prison system that does not incorporate their concerns are significant. Such consequences include not only high levels of sexual and physical violence but the provision of a level of medical treatment that is highly contingent on the jurisdiction and type of correctional facility within which he or she is placed. Imperfect medical care and inadequate treatment is the result. Such less than equal treatment cannot be sustained in the operation of the criminal justice system. To do otherwise is to render the idea of the equality of law in relation to transgender persons redundant. 